production on carbohydrate wastes there world be in. creased local production of yeast from locally available material. Thus the only paper from India, where there is much unused molasses, is devoted entirely to hydroearbons.

Enthusiasm for algal foods seems to be waning, but belated interest is now being shown in the blue-green alga, Spirulina, which is a traditional food in several regions. One paper deals with the use of algae for photosynthetic recycling in space stations. The conclusion is essentially that come to at an Institute of Biology symposium in 1960: there will be no advantage in recycling earbon dioxide unless the station is being occupied for several months, and the practice of trying to feed astronauts on unfractionated algae is misguided. The paper by Oswald and Golueke is of more mundane interest. They rely on bacteria to break down the organic matter in sewage and make carbon dioxide; the photosynthetic algae use this and at the same time supply the oxygen that the bacteria need. The mixture of algae and bacteria is used as fodder. This is excellent. In sunny regions algae will grow in nutrient-rich water in any event, and it is much better to have them growing in a tank from which they can be collected, and from which purified water can be drawn off for re-use, rather than having them fouling the waterways as they now do. The paper is marred by some false comparisons between carefully tended algae in California and the yields got by averago farming in regions with a harsh winter. N. W. PIRIE

\section{POP DNA}

DNA : at the Core of Life Itself

By Lawrence Lessing and the Editors of Frortune. Pp. 85. (Macmillan: New York; Collier-Macmillan: London, March 1969.) $22 s 6 d$.

THe awe-inspiring discoveries of the past few decades in molecular biology have, rightly, begun to hit the popular press. Lots of books, in different sizes and shades, are eramming the booksellers' windows. The Double Helix, with its racy style, is now joined by this slim, glossy, pop book peering at the core of life itself--DNA. Just as The Double Helix presented us with a new set of standards in scientific research, so now the editors of Fortune magazine, led by Mr Lawrence Lessing, have provided a new language for the arena in which the mysteries of the versatile DNA molecule have been pierced.

Mr Lessing starts on a well paved-and well troddenroad, "the Master Key to Life". After a scries of big "waves of discovery", including a dig at the Russians, we arrive at a "model in scrap tin" of DNA with its " $5,000,000,000$ 'bits' of DNA = Man". Racing along in top gear, Crick, Nirenberg and Khorana solved the genetic code, Rich worked out how a protein is manufactured, Holley worked out "the exact positions of the 2,500 or more atoms" in transfer RNA, and then we slow down for "the traffic directors". During this panoramic trip we see how "life puts on individual tissue and integument, flesh and blood". At "the traffic directors", we find that "the varieties of proteins are almost as infinite in number as stars in the sky". A little "genetic engineering", and someone is "reported to be grooming" a virus for the "risky experiment" of correcting mutations in man. Already, we gather that scientists at Columbia-Presbyterian Medical Center in New York have joined with Avco Corp. in the first stages of computer scanning of human chromosomes.

Having learnt how the engine works, we then come to the controls. The first glimmer of how a "computeroperated chemical plant" is controlled comes from "the rebels at the Pasteur Institute", "ex-Free French and Resistance Fighters throughout World War II". After France's first scientific Nobel prize for thirty years, we see
"Monod seizing the occasion to launch a blistering attack on a rigid, minister-dominated educational system, laid down by Napolcon, which ... was experiencing no improvement under another rigid military man, de Gaulle". Leaving the General behind, we discover "Seeing-ere-dog RNA" around the corner, an RNA tag which Bonner thinks might draw its chain of histones to shut off a structural gene on the "gelatinous strands". Moving on, with "hands on the genetic throttle", we fly past hormones and "how a plant decides to flower", to "creative federalism in the cell" and "molecular medicine". After" antibodies in the shape of "lock and key in the body"s defenses", we come round the corner again to intervene in human heredity and "I would like to have four hands" by Bonner.

Mr Lessing's book, which received the Albert Lasker Medical Journalism Award, can only hope to get fainthearted approval from scientists.

The scientific content, though not particularls inaccurate, is very limited in its scope. Not even a table of the genetic code is included. But it may be asking too much of a reader who is really interested in understanding recent developments in molecular biology to find the message hidden in this book, overburdened as it is with a style which is too sensational and a political slant. which is not scientific.

M. S. BRETS'HFR

\section{CANCER AND AGEING}

\section{Biological Aspects of Cancer and Aging}

Studies in Pure Line Mice. By L. C. Strong. (lnte'snational Series of Monographs in Pure and Applied Biology, Vol. 31.) Pp. xv+221. (Pergamon: Oxford, London and New York, Decomber 1968.) $75 s$.

Strong seeks to discuss the contributions of predispusing genes and somatic mutations to ageing and carcinogenesis in mice. Attitudes towards genetic factors in diseaseespecially in man-do not always derive exclusively from the evidence. The following quotation from Guticre\% and Williams ${ }^{1}$ illuminates this point: "In an cra when 'environmental determinism' (as Aldous Huxley called it) prevails in people's thinking, the medical profession has been loath to consider the role that inborn traits can play in disease. For many years it was contrary to the policy of leaders in the American Cancer Society, for example, to let the public know that some individuals are innately vulnerable and others are not. It was feared, we presume, that members of the public, thinking heredity to be vastly simpler than it is, might draw erroneous and damag. ing conclusions with respect to themselves".

During this century, many oncologists have been preoccupied with extrinsic carcinogens including ultraviolet and ionizing radiations, chemical carcinogens and co-carcinogens, and oncogenic viruses. By contrast, intrinsic factors have been relatively neglected, although the recent resurgence of interest in the immunology of cancer is an important move in the biological direction. An up to date and comprehensive treatise on the biology of cancer is therefore overdue, and it could help to establish a balanced outlook. In spite of the promise of its title, the book under review does not fulfil this need.

Mastery of language, and the ability to organize his material, cannot be included among Strong's accomplishments. An author, I imagine, generally lavishes extrat care on the first paragraph of his foreword. Strong begins characteristically: "Biological Aspects of Cancer and Aging considers the two problems enumerated in relation to Geneties. There is no attempt to consider other aspects of Biology. The analysis of the several biological characteristics has only been discussed in the text by reference to the aging process (Gerontology)". Many passages in the text achieve complete opacity, and repetitiveness arises because five of the seven chapters are 